\title{
The Urge to Share Knowledge
}

\section{Tereza Turzíková}

Perspektivy teatrologie [Perspectives of Theatrology]. Academic conference. Hosted by Teatrologická společnost in cooperation with Katedra divadelních a filmových studií FF UP, the 22nd Flora Theatre Festival, the journal Divadelní revue with the support of Institut umění - Divadelní ústav. May 17 and 18, 2018. Art Center UP, Olomouc.

In order to progress, every field of study needs time and space for the confrontation of different points of view and to discuss the potent questions that lay ahead. This desirable opportunity was provided by the conference Perspektivy teatrologie, held on May 17 and 18 in the Art Center under the aegis of Palacký University Olomouc. The designated aim of the conference was to present a variety of topics and to discuss contemporary modes of theatre research in the Czech Republic. Encompassing both theoretical and historiographical themes, the program of the conference itself served as a proof of the diversity of attitudes in contemporary Czech theatrological discourse.

The first day of the conference took place in the monumental Baroque Corpus Christi Chapel, one of the many venues that the Art Center provides. The space itself could be considered symptomatic of the overall focus of the six program sections that were scheduled on the first day. The sections provided a glance into mostly historiographical research, ranging from the times of Ancient Greece to recent past in post-war Europe. The first section, named Old Theatre in Moravia and Silesia, itself opened a discussion on the conception of Czech and German theatre history. Jiří Štefanides stressed the necessity to study Czech and German theatre as two interconnected phenomena. In order to do that, academia is required to change the paradigm of Czech theatre as an isolated, self-contained marvel established through the evolution of Czech theatre studies. One of the themes demonstrated in the presentation of Klára Škrobánková was historical multiculturalism, specifically in the region known as Czech Silesia. Škrobánková's upcoming dissertation thesis on German-speaking theatre in Czech Silesia in the $17^{\text {th }}$ and $18^{\text {th }}$ Century illuminates another problem that was discussed at the morning panel of the conference - how is it possible to study a historical matter while having a limited amount of archival materials that may often distort or manipulate reality? The thematically connected presentation of Miroslav Lukáš closed the first section by means of an insight into the research on theatre culture in Mikulov during the years 1812-1819. The next topic thematised different takes on acting throughout the history. Alena Sarkissaan attempted to demystify the principles of acting in Ancient Greece, focusing mainly on the holistic perception of human physicality and emotionality in Ancient thinking. 
Moving spatio-temporally, nevertheless sustaining the topic of the actor's craft, the next presentation explored the life and work of František Leopold Šmíd, the founder of Czech cabaret. Czech theatre developments abroad were discussed via a report on two plays by Josef Topol directed by Jiří Voskovec during his stay in the USA. A peculiar confrontation of different topics presented in the third section began with research on Ostravan cabaret history, followed by another illumination of Ostravan theater history, specifically the work of the director Jan Škoda. Independently of the theme of Ostrava, Helena Spurná presented an upcoming monograph by a collective of authors, which should map the avantgarde in Czech opera. The presentation brought up questions in the following discussion, mainly concerning which authors to incorporate in such representative monograph and how to deal with the production history of different operatic works. The last section of the program dealt with the paradoxes of Czech postwar theatre. The traces of communist propaganda were examined through the study of a highly ideological ballet manifesto and works of opera director Boris Pokrovsky. Tereza Zálešáková postulated her theory on the post-communist musical audience, as a newly originated class with lack of cultural capital but a desire for faux-intellectual status.

The historiographical approach was combined with more theoretical themes during the second conference day. Beginning with section named Beyond Structuralism, the conference audience was presented with Structuralism as an (unfinished) chapter in theatre theory, as well as a method for analysing radio drama. Kateřina Součková offered the so-called blend theory as a new methodological tool for the inspection of experimental productions that Structuralism cannot provide any more. Moving from theory to praxis, the following section focused on the documentation of theatre artefacts from various points of view - from material archiving, through a photographic database of theatrical buildings, to studying theatre as a process and work itself. After a lunch break full of heated discussion, scholars from Department of Theatre Studies in Brno presented the Center for Performativity Research and illustrated the goals of the Center with their own research on performativity and theatricality - namely on court proceedings, political cultural performances, medieval and baroque ecclesiastical ceremonies and performance art itself. Followed up by Jitka Pavlišová and her topic of solo dance as a concept of intertextuality in the $21^{\text {st }}$ Century, the conference took a turn towards contemporary or recent theatre and ways to approach it. It seems that one of the core questions of contemporary theatre is the position of the audience and the viewer as a subject - whether we focus on their mental activation or interpretative freedom. In this regard, one element of the research of the Department for Theatre and Drama Research carried out by Lucia Repašská might illuminate a part of this problematic, as she is using scientific methods in measuring correlations amongst bio signals and autopoietic feedback loops in theatrical praxis. The other practices of the Department that were presented at the conference were Jan Motal's cognitive phenomenology in studying theatre in relation to social dialogue, as well as translational, editorial and publishing activity of Klára Škrobánková and Nad’a Satková. 
As Pavel Drábek concluded in his final should do was apparent during the whole summary, the division between theory conference. The final summary even used and historiography is as apparent as was terms such as 'generational rejuvenation'. the division of the conference into its two Such change also generates conflict and days. Drábek pointed out the necessity to intellectually productive tension. In a situnever forget theory in studying history, as ation like this, it is crucial to remain open well as to view our own position in time and society when we speak of contemporary theatre and theory. The shift in perto dialogue, to be brave enough to face confrontation and to succumb to our urge ception of what theatrology is and what it 